Kim, R. B., \& Chao, Y. (2018). The effect of country of origin on consumer-

based brand equity (CBBE) of Colombian consumers: An empirical investigation

of Samsung vs. Huawei brands. Journal of International Studies, 11(3), 70-81.

doi:10.14254/2071-8330.2018/11-3/6

\title{
The effect of country of origin on consumer-based brand equity (CBBE) of Colombian consumers: An empirical investigation of Samsung vs. Huawei brands
}

\author{
Renee B. Kim \\ School of Business, Hanyang University \\ Seoul, Korea \\ kimrby@gmail.com \\ Yan Chao \\ School of Business, Hanyang University \\ Seoul, Korea \\ Yanchao0823@hotmail.com
}

Abstract. Consumers pay attention to the Country of Origin (COO) of imported goods, and the COO image is claimed to have a considerable impact on how consumers are forming their relationship with a particular brand. Colombia is the third biggest market by the number of mobile users after Brazil and Mexico, and the $2^{\text {nd }}$, after Chile, in penetration rate in the Latin American region. This makes Columbia one of the most important markets with high growth potential in Latin America for global smartphone producers. Competition among global smartphone brands is fierce, and effective branding strategy is an important prerequisite in leveraging rapid growth of Columbian smartphone market and in gaining a competitive market position. The purpose of this paper is to assess the impact of $\mathrm{COO}$ image on consumer-based brand equity (CBBE) formation process and to determine the extent of COO's influence on the consumers' brand loyalty for two global smartphone brands (Samsung from Korea and Huawei from China) in Columbia. Structural equation modeling (SEM) is applied for analysis of these two brands with survey data from Columbian consumer market. The findings show that the COO image plays a more important role for the PQ of Chinese products than those of Korea. This suggests that Colombian consumers may pay more attention to product quality of Chinese smartphone products and brands as compared to Korean ones.

Keywords: country of origin, consumer-based brand equity, perceived quality, Colombia, Samsung, Huawei, smartphone.

JEL Classification: D11, N56, P59

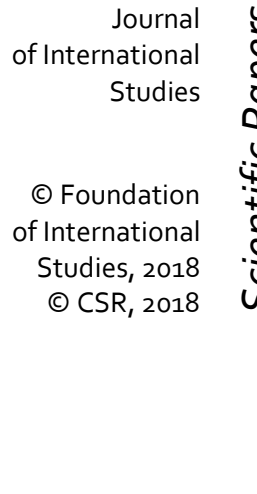

Received:

February, 2018

1st Revision:

May, 2018

Accepted:

August, 2018

DOI:

10.14254/2071-

8330.2018/11-3/6 


\section{INTRODUCTION}

In today's globalizing marketplace, consumers faced the constantly increasing choice of products and brands, while firms are pressured to compete with domestic and global brand products as the Internet disrupt the marketplace by blurring markets' boundaries. Firms need to create brand equity perceived by consumers in order to distinguish themselves from competitors and gain a competitive advantage in the marketplace. Consumer-Based Brand Equity (CBBE) is essential for driving customer equity, differentiating brands, assessing brand performance and maintaining distinctive images in the marketplace (Cifci et al., 2016). Consumers are heavily influenced by brand when it comes to choosing a product and a strong and clear brand image can increase consumer confidence and convince consumers to purchase (Ahmed, 1991). Thus, branding strategy must be an integral part connecting brand image and reflecting the value of a product (Knapman, 2012). An effective branding strategy that induces distinctive ties between a brand and their audiences (consumers) nurtures a long-term buying behaviour of consumers, which consequently, results in consumer-based brand equity (CBBE) (Keller, 2013).

When consumers make a purchase decision concerning an imported product, they tend to evaluate products by considering two types of cues assisting their purchase decisions. A cue can be defined as informational stimuli, which are available to consumers prior to consumption. Consumers evaluate intrinsic cues (taste, design or ingredients) or extrinsic cues (brand, price and country-of-origin (COO)) while making their purchase decision. When consumers are more involved in a given product category (i.e., buying a smartphone), they are likely to be more selective on cues and rely heavily on the selected cues, and COO is one of the most often selected extrinsic cues by consumers under such circumstances (Zafar et al., 2012). Thus, COO may be an important determinant, influencing consumers' choice of imported smartphone products. When consumers face foreign brands, $\mathrm{COO}$ may have a significant impact on their choice behaviour and have a significant impact on consumers' relationship with a particular brand.

In developing countries, consumers may have a reasonably high preference for imported goods, for a low price or appropriate ratio between quality and price. Particularly, consumers pay attention to the COO of imported goods, which has high priority for them and has a significant influence on their purchase (Moradi and Zarei, 2012). Saydan (2013) states that consumers' perceived COO image affect brand recall, constituting brand value, brand awareness, perceived quality and brand loyalty directly and the buying decision of consumers through brand equity. Thus, "country effect" is a critically important factor in terms of market performance of a brand (or product) at the international markets. Therefore, brands can be considered to be highly affected by the COO image.

Colombian smartphone market is selected for the analysis due to its rising market prospects. Colombia has joined Brazil and Mexico at the summit of the smartphone market in Latin America (eMarketer, 2015), the number of smartphone users showed a rapid increase of $43 \%$ in 2 years only, from $11.7 \mathrm{mln}$ users in 2013 to $16.7 \mathrm{mln}$ users in 2015 (Statista, 2016). This makes Colombia the $3^{\text {rd }}$ biggest market by the number of mobile users after Brazil and Mexico, and the $2^{\text {nd }}$, only after Chile, in terms of penetration rate in the Latin American region (eMarketer, 2014).

The smartphone market in Colombia is expected to continue its growth as the Colombian Ministry of Information, Communication\& Technology has launched the "Vive Digital Colombia Plan". This plan aims at "widespread adoption of Internet and the development of a nationwide digital ecosystem" by quadrupling the number of internet connections (Euromonitor, 2015). Columbian government considers mobile industry to be the key strategic sector for regulation and promotion due to its high market concentration and its significant impact on the society. The ICT regulatory framework was created to guarantee favourable business environment for ICT carriers and to encourage investments in this sector in order to deploy the mobile phone service in Colombia (Euromonitor, 2015). Thus, Columbia is indeed one of the most 
important markets in Latin America for global smartphone producers, given its favourable regulatory environment that facilitates rapid growth of smartphone usage in the nation.

Top selling mobile phone brands in Colombia are Samsung, Huawei and Apple, and the competition among these global brands is fierce. In order to sustain their positions as major players at the mobile phone market of Columbia, it would be useful for these brands to have a clear insight on what determines consumers' choice of smartphone and what forms consumers' brand loyalty towards a particular brand. Understanding consumer brand loyalty structure enables incorporation of major determinants of brand loyalty into brand strategy, leading to more effective connection with consumers. Branding plays an integral role in acquiring and maintaining a long-term competitive advantage (Ha et al., 2010; Chang \& Liu, 2009; Boo et al., 2009; Moradi \& Zarei, 2012). Thus, powerful brands lead competitive advantages, raise organization cash flows, accelerate liquidity, provide premium price, profitability and make customers loyal (Moradi and Zarei, 2012). The purpose of this paper is to conduct a comparative analysis on the effect of Country of Origin image on brand equity of two global smartphone brands (Samsung vs. Huawei) on the example of Columbian consumer market.

\section{LITERATURE REVIEW}

\subsection{COUNTRY OF ORIGIN (COO)}

The study of Country of Origin (COO) has been one of the most widely researched concepts in marketing and consumer behaviour since Robert Schooler framed the construct in 1965 (Papadopolous and Heslop 2002; Roth \& Diamantopoulos, 2009). COO has been defined as "the country where the product was manufacture" (Bamber et al, 2011; Prandeargast et al, 2010). In some studies, "Made in China", has become one of the most visible labels (Fan, 2006; Lyles, Flynn, \& Frohlich, 2008; Sull \& Wang; 2005), conveying both positive and negative meanings about products made in China and product-related image of China (Han \& Wang, 2012; Harney, 2008; Interbrand, 2007; Loo \& Davies, 2006; Morrison, 2008; Ryan, 2007). For example, the recent "Made-in-China" crises (i.e., toy recalls, dairy products scandals, and toxic capsules) have led to consumers' concern about importing and buying "Made in China," which in turn may result in an image problem for Chinese brands and for China as a whole. COO serves as an extrinsic informational cue for consumers' perception s and evaluations of a product, acting as a signal of product quality, influence consumers' perception of risk and value, affect the likelihood of purchase (Jaffe and Nebenzahl 2006; Pharr 2005; Phau \& Chao 2008). Thus, COO image of import products appears to have a substantial influence on consumers' perception of a brand; therefore, we propose that $\mathrm{COO}$ image is an important exogenous construct affecting consumers' choice behaviour for branded products.

\subsection{CONSUMER-BASED BRAND EQUITY (CBBE)}

It has been argued that brands are complex, but ultimately they rest in the minds of customers as a basis on which to identify with a product, quality and image that is portrayed (Beamish and Ashford, 2007). Brand equity is acknowledged as a key marketing performance indicator, a source of competitive advantage, and a vital component of business (Christodoulides et al. 2015). A brand has high brand equity when it generates positive connotations in the consumers' minds and is therefore likely to be the preferred purchase over other brands or non-branded products, creating brand loyalty (Pappu et al, 2005; Yoo et al, 200; Kuhn et al, 2008; Arvidsson, 2006). Customer-based brand equity (CBBE) is proposed to be the dominant framework, which is used by many marketing research, as it, highlights the creation of brand equity (Davcik et al. 2015). CBBE is "a set of perceptions, attitudes, knowledge, and behaviours on the part of consumers 
that results in increased utility and allows a brand to earn greater volume or greater margins than it could without the brand name (Christodolides \& Chernatory, 2010). Thus, brands with high brand equity can charge a premium price for their products (Kuhn et al, 2008; Arvidsson, 2006).

\subsection{DEVELOPMENT OF HYPOTHESES}

Keller (1993) specified that CBBE's constructs: brand awareness, brand association, perceived quality lead to brand loyalty. In this study, we follow Keller's CBBE framework and selected two constructs Perceived Quality (PQ) and Brand Awareness/Associations (BA) as two key drivers forming consumers' Brand Loyalty (BL). PQ is defined as the customer's perception of the overall quality or superiority of a product or service with respect to its intended purpose, relative to alternatives (Aaker, 1993); BA is defined as anything linked in memory to a brand, usually in some meaningful way. We combined brand awareness and brand associations in our study as Washburn and Plank (2002) suggested that the scale items measuring brand association and brand awareness are not distinct. BL is defined as a measure of the attachment a customer has to a brand which is considered to be the final step or an outcome in the CBBE process (Keller, 1996) being the most influential factor in building a strong brand. In this study, COO is proposed to have an exogenous effect on the CBBE process, influencing directly on consumers' PQ and BA. The image of the COO can strongly impact consumers' perception of products and brands (Nagashima, 1970), including evaluation of quality (Hong \& Wyer, 1989; Roth \& Romeo, 1992). The COO construct is hypothesized to affect the PQ and BA constructs directly, and the PQ and BA constructs are expected to affect the BL construct. The proposed model tests whether an antecedent -the COO is related to CBBE constructs and assesses if the $\mathrm{COO}$ is a major determinant for a successful customer-brand relationship in foreign markets (Table 1).

Table 1

Hypotheses of the Proposed CBBE Model

\begin{tabular}{|c|l|}
\hline No. & \multicolumn{1}{|c|}{ Hypothesis statement } \\
\hline H1a & COO image of Samsung (Korea) has a positive relationship with PQ \\
\hline H1b & COO image of Huawei (China) has a positive relationship with PQ \\
\hline H2a & COO image of Samsung (Korea) has a positive relationship with BA \\
\hline H2b & COO image of Huawei (China) has a positive relationship with BA \\
\hline H3a & PQ of Samsung smartphone positively affects consumer's BL \\
\hline H3b & PQ of Huawei smartphone positively affects consumer's BL \\
\hline H4a & BA of Samsung smartphone positively affects consumer's BL \\
\hline H4b & BA of Huawei smartphone positively affects consumer's BL \\
\hline H5 & There are significant differences between PQ of Samsung and Huawei smartphone by consumers \\
\hline H6 & There are significant differences between BA of Samsung and Huawei smartphone by consumers \\
\hline H7 & There are significant differences between BL of Samsung and Huawei smartphone by consumers \\
\hline
\end{tabular}

\section{METHODOLOGY}

\subsection{MEASURES}

In this study, two COO are selected, Korea and China and 'Samsung' and 'Huawei' brands are selected for smartphone product category for assessing Colombian consumers' perception and choice behaviour. These two brands and relevant COOs are selected based on the following reasons: (1) smartphone is a high-involvement product category in which consumers invest extensive time for information search, and brand \& COO are two important extrinsic cues in their search process, and (2) Samsung and Huawei are 
two brands which take up $48 \%$ of the Columbian smartphone market, implying high level of brand awareness for these brand products among Colombian consumers.

The items used for the measurement in this present study were selected based on the previous studies: the COO construct, (Hadi Azim Arei, 2012; Khosrozadeh Shirin, 2011), Perceived Quality (Jalilvand et al., 2011), Brand Awareness (Hadi Azim Zarei, 2012; Norjaya Yasin, 2000), and Brand Loyalty (Jalivand et al., 2011). In total, sixteen items were measured with four constructs; these items were measured with five-point Likert scales (i.e. $1=$ strongly agree, $2=$ disagree, $3=$ neutral, $4=$ agree, and $5=$ strong agree).

\subsection{SAMPLING AND DATA COLLECTION}

A convenience sampling method was used to collect survey data and the survey questionnaire was designed in the Google online survey form in 2016. To collect survey data, Colombian citizens were contacted through Facebook, and the link to a survey questionnaire (www.google.com/forms/about) was distributed to the participants by using online method. All participants voluntarily joined a survey. The survey questionnaire was originally created in English and translated into Spanish for Columbian consumers. The survey questionnaire was processed through a back translation Spanish-English again in order to avoid the missing context. Sixteen questions were included in the survey for the smartphone brand, Samsung and Huawei. In total, 340 questionnaires were collected and 315 usable data were processed for statistical analysis.

\section{DATA ANALYSIS}

\subsection{DESCRIPTIVE SAMPLE CHARACTERISTICS}

Preliminary data analysis shows that the data represents approximately $50 \%$ of male and $50 \%$ of female participants. The data consists of consumers with the largest proportion of the age group between 21 to 30 years old, with a college education. In terms of smartphone usage, $58 \%$ of the marker is taken by iPhone mobile users, while $28 \%$ and $3 \%$ of the market is taken by Samsung and Huawei mobile users, respectively, and the remaining market is made of other brands.

\subsection{RELIABILITY AND VALIDITY ANALYSIS}

Exploratory Factor Analysis (EFA) was carried out for the two models of Samsung and Huawei brands, and findings showed that the items were pooled into four factors for both Samsung and Huawei models, and all items were loaded in their single factor without any cross-loadings. EFA results show that all items had a satisfied requirement, which was above 0.5. Cronbach's Alpha ( $\alpha$ ) test resulted in 11 items that were statistically acceptable, and for both the Samsung and the Huawei model, the Composite Reliability (CR) was greater than 0.06 and Average Variance Extracted (AVE) exceeded 0.50, revealing the achievement of convergent validity.

Confirmatory Factor Analysis (CFA) was performed and the $\chi^{2}$ statistical results for Samsung (Korea) suggest a good model fit (CMIN/DF=1.401; NFI=0.98; CFI=1.00; TLI=0.99; RMSEA=0.021)(Table 2). The $\chi^{2}$ statistical results for Huawei (China) was also found to have a good fit of the measurement $(\mathrm{CMIN} / \mathrm{DF}=1.179 ; \mathrm{NFI}=0.98 ; \mathrm{CFI}=0.99 ; \mathrm{TLI}=0.98 ; \mathrm{RMSEA}=0.045)$. 
Fit indices for the measurement model

\begin{tabular}{|l|c|c|c|}
\hline Fit indices & $\begin{array}{c}\text { Samsung } \\
\text { Measurement models }\end{array}$ & $\begin{array}{c}\text { Huawei } \\
\text { Measurement models }\end{array}$ & $\begin{array}{c}\text { Recommended } \\
\text { Values }\end{array}$ \\
\hline $\boldsymbol{\chi}^{\mathbf{2}} \mathbf{d f}$ & 1.401 & 1.179 & $\leq 3.00$ \\
\hline Comparative fit index (CFI) & 1.00 & 0.99 & $\geq 0.90$ \\
\hline Normal Fit Index (NFI) & 0.98 & 0.98 & $\geq 0.90$ \\
\hline Tucker-Lewis Index (TLI) & 0.99 & 0.98 & $\geq 0.90$ \\
\hline RMSEA & 0.021 & 0.045 & $\leq 0.05$ \\
\hline
\end{tabular}

\section{EMPIRICAL RESULTS}

\subsection{GOODNESS OF FIT STATISTICS}

Goodness of fit statistics for two structural models for Samsung and Huawei brands were estimated and the results suggest that the structural models for Samsung brand had a satisfactory model fit $(\mathrm{CMIN} / \mathrm{DF}=1.5 ; \mathrm{GFI}=0.97$; TLI=0.98; $\mathrm{CFI}=0.99 ; \mathrm{RMSEA}=0.04)$, and the model for Huawei brand also show a reasonable goodness of fit $(\mathrm{CMIN} / \mathrm{DF}=1.5 ; \mathrm{GFI}=0.97$; TLI=0.98; $\mathrm{CFI}=0.99 ; \mathrm{RMSEA}=0.041)$.

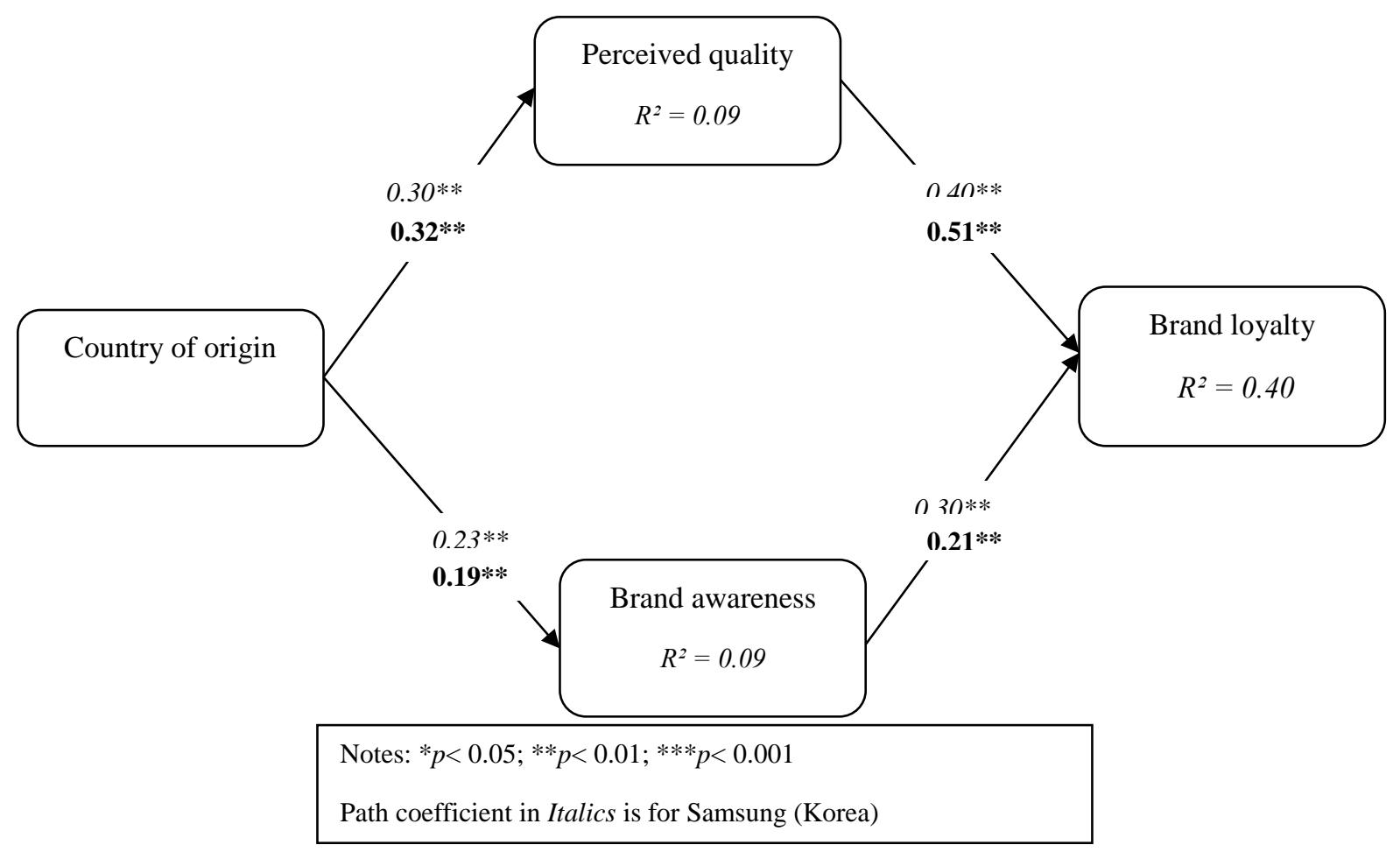

Figure 1. Path coefficients of the research model*

\subsection{PATH COEFFICIENTS OF FOUR CONSTRUCTS - COO, PQ, BA \& BL}

Findings show that the relationships among the four selected constructs are statistically significant and positive. Estimated path coefficients between the County of Origin (COO) and the Perceived Quality (PQ) 
constructs is statistically significant both for Samsung brand case (path coefficient $=0.30$ with positive $\mathrm{P}$ value at $p<0.001$ ) and for Huawei brand case, (path coefficient $=0.32, p<0.001$ ) (Figure 1). The COO constructs also influence the Brand Association/Awareness (BA) construct positively for both Samsung and Huawei brands (path coefficient $=0.23 ; 0.19$, respectively; significant at $p<0.001 ; p<0.001$ ). The PQ and the BA constructs directly influence the Brand Loyalty (BL) construct (path coefficient $=0.04, p<0.001$; and path coefficient $=0.30, p<0.001$ ) for Samsung brand and for Huawei brand (path coefficient $=0.51$, $p<0.001)$; (path coefficient $=0.21, p<0.001)$.

\subsection{DIFFERENCE BETWEEN SAMSUNG VS. HUAWEI BRANDS FOR CBBE CONSTRUCTS}

Samsung and Huawei smartphones are two leading foreign brands with dominant positions in the Columbian smartphone market, and the Columbian consumers may have different perceptions toward these two brands that may result in different values of CBBE constructs. ANOVA test results show that the three selected CBBE constructs of Samsung and Huawei brands are found to be statistically different (Table 3).

Table 3

ANOVA Statistics of Samsung \& Huawei CBBE Model Constructs

\begin{tabular}{|l|l|l|l|l|}
\hline Constructs & Brand & Mean & SD & F \\
\hline \multirow{2}{*}{ Perceived Quality (PQ) } & Samsung & 13.1 & 2.27 & $268.0^{* *}$ \\
\cline { 2 - 6 } & Huawei & 10.0 & 2.62 & \\
\hline \multirow{2}{*}{ Brand Association/Awareness (BA) } & Samsung & 13.4 & 4.16 & $227.5^{* *}$ \\
\cline { 2 - 6 } & Huawei & 8.77 & 3.76 & \\
\hline \multirow{2}{*}{ Brand Loyalty (BL) } & Samsung & 8.82 & 1.60 & $270.8^{* *}$ \\
\cline { 2 - 6 } & Huawei & 6.28 & 2.31 & \\
\hline
\end{tabular}

Notes:** $p<0.01$

\section{DISCUSSION}

The objective of this study is to investigate the impact of Country of Origin (COO) on Consumerbased brand equity (CBBE) model in the Colombian smartphone market with two major import brands from Korea and China. Given the rising popularity and reputation of these two smartphone brands in Colombia, this study contributes to the existing literature by providing implications for brand products from two major Asian smartphone producers as well as other Korean and Chinese firms who are interested in marketing products in Colombian markets. Online survey was conducted in Colombia with 315 participants by convenient sampling and the results support that the COO images of Korea and China are found to influence Colombian consumers' Perceived Quality (PQ) and Brand Awareness (BA) of Samsung and Huawei brands, which are two main determinants of consumers' Brand Loyalty (BL).

At large, the COO construct appears to have a greater impact on the PQ construct compared to the BA construct in both of Samsung and Huawei CBBE models, and the PQ construct has the greatest effect on the BL construct for both models (Table 4). In other words, the Perceived Quality (PQ) of import brands is a critical driver determining Colombian consumers' choice for a smartphone. The BA construct also affect the BL construct in the models, but the effect is to a lesser degree compared to the PQ (Table 4). This implies that Colombian consumers' purchase intention for import smartphone brand is more heavily affected by perceived quality rather than brand association/awareness of the foreign brands. 
Table 4 reports that the path coefficients among the four selected constructs of Samsung and Huawei CBBE models are found to be different. The PQ of Huawei is more heavily affected by the COO image compared to Samsung's case, implying that Chinese COO image has a significantly greater effect on perceived quality of Chinese brand products.

On the other hand, the BA of Samsung is more heavily affected by its COO image compared to that of Huawei. Samsung brand has relatively much larger market share compared to Huawei and has more prevalent branding and promotion activities in Columbia, thus Colombian consumers may have more sources where they find cues to relate Samsung brands' elements with Korean COO. Korea's COO image may be closely related to the BA of Samsung brand, leading to Brand Loyalty (BL) of the Colombian consumers.

Samsung is actively leveraging the positive value of 'Hallyu' in their branding and advertising activities, which is a positive aspect of Korea's COO image. Thus, Samsung's branding campaign that combined with Hallyu may effectively raise its BA, which results in BL for Samsung products. Jung (2006) examined the relationship between Hallyu and the Korean COO image and validated the positive effect of Hallyu on Korea's COO image. In return, the BA of Samsung is relatively higher than that of Huawei, and COO image of Samsung has a more positive effect on Samsung brand's CBBE.

Country of Origin (COO) image has a major role in how consumers are forming their relationship with a foreign brand; particularly it has a critical impact on consumers' perception of product quality thereby affecting their choice of a particular brand. Regarding the effects of the COO in the CBBE, findings in this study are supported by previous studies (Murtiasih et al., 2013 and Mostafa, 2015; Fischer et al., 2012; Knight and Calantone, 2000). Various studies validate the relationship between COO and CBBE. Consumers' macro and micro country images can affect the equity they associate with a brand from that country. Pappu et al. (2007) showed that the US origin image had an effect on CBBE of a brand (i.e. IBM or Apple computer brands) in the Australian market. Their study suggests that COO image can influence the key dimensions of brand equity such as brand associations, perceived quality and brand loyalty (Pappu et al., 2007).

Table 4

Empirical Results of Path Analysis for Samsung \& Huawei

\begin{tabular}{|l|c|c|c|c|}
\hline & \multicolumn{2}{|c|}{ Path Coefficient Estimates } & \multicolumn{2}{c|}{$P$} \\
\hline Path Relationship & Samsung(Korea) & Huawei (China) & Samsung (Korea) & Huawei (China) \\
\hline $\mathrm{COO} \rightarrow \mathrm{PQ}$ & $.305^{* * *}$ & $.323^{*}$ & $<0.001$ & 0.010 \\
\hline $\mathrm{COO} \rightarrow \mathrm{BA}$ & $.226^{*}$ & .185 & 0.011 & 0.033 \\
\hline $\mathrm{PQ} \rightarrow \mathrm{BL}$ & $.404^{* * *}$ & $.508^{* * *}$ & $<0.001$ & $<0.001$ \\
\hline $\mathrm{BA} \rightarrow \mathrm{BL}$ & $.304^{* *}$ & $.21^{* *}$ & 0.003 & 0.002 \\
\hline
\end{tabular}

\section{CONCLUSION}

Findings from this study support a positive relationship among CBBE constructs such as PQ, BA and BL. Some studies presented similar findings for CBBE structure, considering the CBBE as a multidimensional hierarchical construct with causal relationships among its components (Hsu et al., 2011; Buil 2013; Nguyen et al., 2011). Hsu et al. (2011) and Nguyen et al. (2011) showed that PQ has a greater impact on BL compared to BA. These study results imply the importance of ensuring high quality in the minds of consumers in establishing consumers' brand loyalty.

Our study findings showed that perceived quality is found to have the greatest impact for brand loyalty of both Samsung and Huawei. For Samsung, COO and brand awareness were found to have equivalent 
importance in leading to brand loyalty, while $\mathrm{COO}$ had much greater effect for Huawei brand, compared to brand awareness. This suggests that the Colombian consumers may pay more attention to product quality of 'Chinese' smartphone products compared to 'Korean' ones. Furthermore, the perceived quality of Chinese products had a stronger effect on consumers' brand preference compared to that of Korean products.

Korea has improved its $\mathrm{COO}$ image in the past decade with an increasing rate of international tourists to Korea. In 2010, the number of foreign visitors to Korea was around 8.8 million people (a 12.5\% increase since 2009) (Foreign tourists, 2010; cited in Yu, Kim and Kim, 2012). The impact of Korean wave namely known as "Hallyu" in the Korean language, as well as the popularity of Korean drama and pop music, socalled 'K-drama' and 'K-pop' through media, have been claimed to contribute to the popularity of Korean made goods and products among international customers (Rahmiati, 2012). The Hallyu refers to the cultural aspects by which people in Japan, Taiwan, Hong Kong, Vietnam, and other countries in Asia and other parts of the world, through Korean music, dramas, films and games, yearn for, follow, and are willing to adopt Korean popular culture (Jung, 2006; cited in Yu, Kim, and Kim, 2012). Korean firms strive to leverage the positive value of Hallyu in their branding, by making advertising and promotional campaign with internationally acclaimed K-pop or K-drama celebrities. Effective marketing of Hallyu may have implicit positive effects on Korea's COO image for products with Korean products. Consequently, COO image of Korea has positive effect on brand awareness of Korean brand, leading to brand loyalty for Korean brand. In comparison, $\mathrm{COO}$ image of China appears to play lesser important role in brand awareness of Chinese products.

In case of China, 'Made in China' products are prevalent in the world market. Despite the rapid growth of China as a leading manufacturer in the world in recent years, the quality of Made-in-China' products is still being perceived to be negative (Lew \& Sulaiman, 2013). The reputation of 'Made in China' has been known to be negative in consumers' mind for the past decade (Ahmed, Johnson, Xia \& Chen, 2014). Being the second largest economy after the US, China has ventured into many product developments to compete with the international giants (Kerbouche, Adouka, Belminoun \& Guenouni, 2012), and with this competitive upsurge, China strives to improve its COO image in order to improve its position in the international consumer markets. The rapid growth of Corporate China is expected to lead to investment in improving its COO image, and with enhanced image perceptions of Made-in-China products, Corporate China is anticipated to gain more competitive position in near future (Nor Sara Nadia Muhamad Yunus, Wan Edura Wan Rashid, 2016). In short, the success of Chinese brand may significantly depend on whether they can communicate the product quality in order to convince Columbian consumers and to gain their loyalty. Overall, both Korean and Chinese smartphone brands may need to recognize the significant role their County Origin (COO) plays in the process of Columbian consumers' brand preference formation, and they need to develop effective communication strategies to promote and emphasize strength in the quality of their products to gain competitive advantage in this market.

\section{ACKNOWLEDGEMENT}

This work was supported by the Ministry of Education of the Republic of Korea and the National Research Foundation of Korea(NRF-2016S1A3A2924243).

\section{REFERENCES}

Aaker, D. (1993). Are brand equity investments really worthwhile. Brand equity and advertising: Advertising's role in building strong brands, 333-341. 
Ahmed, Z. U, Johnson, J. P., Xia, Y., \& Chen, K. F. (2014). Does Country of Origin Matter for Low-Involvement Products?. International Marketing Review, 21(1), 102-120.

Ahmed, Z. U. (1991). The influence of the components of a state's tourist image on product positioning strategy. Tourism management, 12(4), 331-340.

Ahmed, Z. U., Zbib, I. J., Sikander, A., \& Gilbert Noujaim, R. (2012). Does country of brand origin (COBO) matter for the Lebanese consumers?. EuroMed Journal of Business, 7(2), 108-128.

Arvidsson, A. (2006). Brand Value. Brand Management, 13(3), 188-192.

Bamber, D., Phadke, S., \& Jyotishi, A. (2011). Product Knowledge, Ethnocentrism and Purchase Intention: COO Study in India. Amrita Vishwa Vidyapeetham. University- working paper 112/2011.

Boo, S., Busser, J., \& Baloglu, S. (2009). A model of customer-based brand equity and its application to multiple destinations. Tourism Management, 30(2), 219-231.

Buil, I., De Chernatony, L., \& Martínez, E. (2013). Examining the role of advertising and sales promotions in brand equity creation. Journal of Business Research, 66(1), 115-122.

Chang, H. H., \& Liu, Y. M. (2009). The impact of brand equity on brand preference and purchase intentions in the service industries. The Service Industries Journal, 29(12), 1687-1706.

Christodoulides, G. \& de Chernatory, L. (2010). Consumer-based brand equity conceptualization and measurement. International Journal of Market Research, 52(1), 43-66.

Christodoulides, G. Cadogan, J.\& Veloutsou, V. (2015). Consumer-based brand equity measurement: Lessons from an international study. International Marketing Review, 32(3/4), 307-328.

Cifci, S., Ekinci, Y., Whyatt, G., Japutra, A., Molinillo, S., \& Siala, H. (2016). A cross-validation of Consumer-Based Brand Equity models: Driving customer equity in retail brands. Journal of Business Research, 3740-3747.

Davcik, N. \& Sharma, P. (2015). Impact of product differentiation, marketing investments and brand equity on pricing strategies. European Journal of Marketing, 49(5/6), 760-781.

eMarketer, (2014). Colombia joins top three smartphone markets in Latin America. There will be 14.4 million smartphone users in the country in 2014. Retrieved from http://www.emarketer.com/Article/Colombia-Joins-Top-ThreeSmartphone-Markets-Latin-America/1011750 [assessed July 13, 2016].

eMarketer, (2014). The Competitive Intelligence Unit (CIU) as cited in company blog;eMarketer calculations, June 11, 2014. Retrieved from http://www.emarketer.com/Article/Colombia-Samsung-Huawei-Conquer-SmartphoneMarket/1012631 [assessed July 13, 2016].

Euromonitor. (2015). Mobile phones in Colombia. Retrieved from http://www.euromonitor.com/mobile-phones-incolombia/report [assessed July 13, 2016].

Fan, Y. (2006). The globalisation of Chinese brands. Marketing Intelligence \& Planning, 24(4), 365-379.

Ha, H. Y., Swinder, J., \& Siva, M. (2010). Development of brand equity: evaluation of four alternative models. The Service Industries Journal, 30(6), 911-928.

Han, G. \& Wang, X. (2012). Understanding "Made in China": Valence framing and product-country image. Journalism \& Mass Communication Quarterly, 89(2), 225-243.

Harney, A. (2008). The China price: The true cost of Chinese competitive advantage. New York, NY: The Penguin Press.

Hong, S. T., \& Wyer Jr, R. S. (1989). Effects of country-of-origin and product-attribute information on product evaluation: An information processing perspective. Journal of Consumer Research, 16(2), 175-187.

Hsu, C. H., Oh, H., \& Assaf, A. G. (2011). A customer-based brand equity model for upscale hotels. Journal of Travel Research, 0047287510394195.

Interbrand. (2007). Made in China: 2007 brand study (Shanghai: Interbrand China). Retrieved from http://www.ourfishbowl.com/images/surveys/Interbrand_Made_In_China_2007.pdf.

Jaffe, Eugene D. \& Israel, D. Nebenzahl. (2006). National Image and Competitive Advantage. Copenhagen: Copenhagen Business School Press.

Jalilvand, M. R., Samiei, N., \& Mahdavinia, S. H. (2011). The effect of brand equity components on purchase intention: An application of Aaker's model in the automobile industry. International business and management, 2(2), 149-158.

Jung, Hyung-Shik (2006). The Effect of Consumer's Perception of Korean Wave (Hallyu) on Korean Product Purchase and Country Image in Chinese Market. Journal of Consumer Studies, 17(3), 79-102.

Keller, K. L. (2013). Strategic Brand Management: Building, Measuring, and Managing Brand Equity (4th ed.). Boston, MA: Pearson.

Kerbouche, M., Adouka, L., Belminoun, A., \& Guenouni, H. (2012). The Country of Origin and the Consumer Behavior: How to Improve Chinese Products Brands?. Mediterranean Journal of Social Sciences, 3, 551-552. 
Knapman, S. (2012, April 23). PRWeek. Retrieved 06 20, 2012, from www.prweek.com: http://www.prweek.com/uk/research/1127888/rise-smartphones-means-brands/.

Kuhn, K. A. L., Alpert, F., \& Pope, N. K. L. (2008). An application of Keller's brand equity model in a B2B context. Qualitative Market Research: An International Journal, 11(1), 40-58.

Lew, S., \& Sulaiman, Z. (2014). Consumer purchase intention toward products made in Malaysia vs. made in China: A conceptual paper. Procedia-Social and Behavioral Sciences, 130, 37-45.

Lita, R., \& Cho, Y. C. (2012). The influence of media on attitudinal And Behavioral Changes: Acceptance Of Culture And Products. The International Business \& Economics Research Journal (Online), 11(12), 1433-1444.

Loo, T., \& Davies, G. (2006). Branding China: The ultimate challenge in reputation management?. Corporate Reputation Review, 9, 198-210.

Lyles, M. A., Flynn, B. B., \& Frohlich, M. T. (2008). All supply chains don't flow through: Understanding supply chain issues in product recalls. Management and Organization Review, 4(2), 167-182.

Mohd Yasin, N., Nasser Noor, M., \& Mohamad, O. (2007). Does image of country-of-origin matter to brand equity?. Journal of Product \& brand management, 16(1), 38-48.

Moradi, H., \& Zarei, A. (2012). Creating consumer-based brand equity for young Iranian consumers via country of origin sub-components effects. Asia Pacific Journal of Marketing and Logistics, 24(3), 394-413.

Moradi, H., \& Zarei, A. (2012). Creating Consumer-Based Brand Equity for Young Iranian Consumers via SubComponents Country of Origin Effects. Asia Pacific Journal of Marketing and Logistics, 24(3), 394-413.

Moradi, H., \& Zarei, A. (2012). Creating consumer-based brand equity for young Iranian consumers via country of origin sub-components effects. Asia Pacific Journal of Marketing and Logistics, 24(3), 394-413.

Morrison, W. M. (2008). China-U.S. trade issues. Key workplace documents federal publications. Retrieved from http://digitalcommons.ilr.cornell.edu/keyworkplace/498.

Mostafa, R. H. (2015). The Impact of Country of Origin and Country of Manufacture of a Brand on Overall Brand Equity. International Journal of Marketing Studies, 7(2), 70.

Murtiasih, S., \& Siringoringo, H. (2013). How word of mouth influence brand equity for automotive products in Indonesia. Procedia-Social and Behavioral Sciences, 81, 40-44.

Nagashima, A. (1970). A comparison of Japanese and US attitudes toward foreign products. The Journal of Marketing, 68-74.

Nguyen, T. D., Barrett, N. J., \& Miller, K. E. (2011). Brand loyalty in emerging markets. Marketing Intelligence \& Planning, 29(3), 222-232.

Nor Sara Nadia Mubamad Yunus and Wan Edura Wan Rashid / Procedia Economics and Finance 37 ( 2016 ) pp 343 - 349.

Pappu, R., Quester, P. G., \& Cooksey, R. W. (2005). Consumer-based brand equity: improving the measurementempirical evidence. Journal of Product \& Brand Management, 14(3), 143-154.

Pappu, R., Quester, P. G., \& Cooksey, R. W. (2006). Consumer-based brand equity and country-of-origin relationships: Some empirical evidence. European Journal of marketing, 40(5/6), 696-717.

Pappu, R., Quester, P. G., \& Cooksey, R. W. (2007). Country image and consumer-based brand equity: relationships and implications for international marketing. Journal of International Business Studies, 38(5), 726-745.

Pharr, J. M. (2005). Synthesizing country-of-origin research from the last decade: is the concept still salient in an era of global brands?. Journal of Marketing Theory and Practice, 13(4), 34-45.

Phau, I., \& Chao, P. (2008). Country-of-origin: state of the art review for international marketing strategy and practice. International Marketing Review, 25(4), 349-353.

Prendergast, G., Tsang, A., \& Chan, C. (2010). The Interactive Influence of Country of Origin of Brand and Product Involvement on Purchase Intention. Journal of Consumer Marketing, 27(2), 180-188.

Roth, K. P., \& Diamantopoulos, A. (2009). Advancing the country image construct. Journal of Business Research, 62(7), 726-740.

Saydan, R. (2013). The relationship between Country of Origin Image and Brand Equity: Empirical Evidence in the English Market. International Journal of Business and Social Science, 4(3).

Shirin, K., \& Kambiz, H. H. (2011). The effect of the country-of-origin image, product knowledge and product involvement on consumer purchase decisions. Chinese Business Review, 10(8), 601-615.

Statista, (2016). A number of smartphone users in Colombia from 2013 to 2019 (in million)*. Available at www.statista.com/statistics/467750/forecast-of-smartphone-users-in-colombia/ [assessed July 13, 2016].

Sull, D. N., \& Wang, Y. (2005). Made in China: What Western managers can learn from trailblazing Chinese entrepreneurs. Boston, MA: Harvard Business School Press. 
Washburn, J. H., \& Plank, R. E. (2002). Measuring brand equity: An evaluation of a consumer-based brand equity scale. Journal of Marketing Theory and Practice, 10(1), 46-62.

Yoo, B., \& Donthu, N. (2001). Developing and validating a multidimensional consumer-based brand equity scale. Journal of business research, 52(1), 1-14.

Yoo, B., Donthu, N., \& Lee, S. (2000). An examination of selected marketing mix elements and brand equity. Journal of the academy of marketing science, 28(2), 195-211.

Yu, H., Kim, C., \& Kim, H. (2012). Investigating cosmetics purchase of international tourists in South Korea. International Journal of Management Cases, 14(1), 398-410. 